\title{
Income Self-Sufficiency and Profitability of Professional Theatres in the Czech Republic
}

\section{Jiří Bečica ${ }^{1}$}

\begin{abstract}
The paper assesses the professional theatres operating under the Association of Professional Theatres in the Czech Republic in the period 2011-2015 using the financial analysis, particularly the profitability indicator ratio (ROA, ROCE, ROE, ROS) and the rate of income self-sufficiency. The reason for this economic exploration of theatres is in the fact that the service they provide fall under collectively provided public goods (a common feature of most cultural institutions), and that the market is not able to effectively secure these goods on the profit principle. The J. K. Tyl Theatre in Pilsen, the Drak Theatre in Hradec Králové and the Moravian Slovakia Theatre in Uherské Hradiště have reported the best results of profitability indicators. Whereas the worst results in profitability have been reported for the North Bohemian Theatre of Opera and Ballet in Ústí nad Labem, the Antonín Dvořák Theatre in Př́ibram and the South Bohemian Theatre in České Budějovice. The rate of income self-sufficiency within 2011-2015 ranges from 12-55\% of the total budget volume, and volume and shows a strong dependency of professional theatres on foreign resources, particularly from public resources of the local levels of the government being the most common funder of these cultural institutions. It turns out that, from the economic point of view, it is illogical to transform non-profit contributory organizations in culture with a public funder into a different legal form when the purpose of the establishment and the funder remain preserved. Better results are generally obtained from single-genre theatres and, in terms of the auditorium size, smaller theatres focusing on drama or children's production.
\end{abstract}

Keywords: culture, income self-sufficiency, profitability, theatre,

JEL Classification: H 39, H 44, H76, L 31, L 83, P 35, Z 11

Received: 4 January 2017 / Accepted: 19 May 2018 / Sent for Publication: 3 September 2018

\section{Introduction and a review of literature}

Culture does not only represent our history but also the present and the future. Provision of public services to citizens in the field of culture is guaranteed in the Czech Republic based on the government's adopted cultural state policy for the years 2015-2020 (Ministry of Culture of the Czech Republic). Cultural funding has been attention to from

\footnotetext{
1 Ing. Bc. Jiří Bečica, Ph.D.; Department of Public Economics, Economic Faculty, VŠBTechnical University Ostrava, Sokolská 33, 70121 Ostrava 1, Czech Republic, jiri.becica@vsb.cz 
various government levels in the Czech Republic, which is usually due to the inability of cultural organizations to economically secure their functioning on the market.

The inefficiency of most cultural institutions in the Czech Republic is due to the excess supply in the market and an unbalanced (insufficient) number of those creating demand. However, the imbalance on the market in culture cannot be solved simply, e.g. by reducing the capacity of the auditoriums of theatres, concert halls, exhibition spaces, or the number of exhibited objects or objects held in the deposit.

The aim of the paper is to evaluate the economic operation in selected cultural organizations provided by public services with a collective consumption. The theatres chosen for the examination are those operating under the Association of Professional Theatres in the Czech Republic in the period 2011-2015. The paper examines whether private theatres, specifically the legal form of limited liability companies, are better managed within professional theatres, or whether they represent a more stable form of professional theatres in the Czech Republic. The point of reference for a quality management are the individual results of the financial analysis of the groups of proportional ratios, namely the profitability indicator ratios. In addition, the income selfsufficiency indicator, a modification with non-profit organizations of a commonly used index of autarky (Kraftová, 2002, p. 101), has been chosen and shows the degree of the institution's financial independence on its funder.

The evaluation of the effectiveness of cultural institutions in the provision of public services has been dealt with by a great number of Czech authors (Ochrana, 2007, Stejskal, 2013, Richter, 2015 or Vrabková, 2017). Most authors use popular multicriteria evaluation methods (DEA, WSA, TOPSIS, ELECTRE, etc.) to evaluate their selected sample of organizations. These methods are used by the authors in varying degrees to evaluate the selected criterion (inputs or outputs) or the assigned weight according to chosen preferences (e.g. Vavrek, Admisin, Kotulic, 2014). The assessment of professional theatres based on proportional ratios of financial analysis is, however, a unique approach and has not yet been carried out to such an extent and form.

According to Žáková (2017), the theatrical production is sorted in the cultural and creative industry, where, in addition to scenic arts, also belongs architecture, design, digital games, film, music industry, books and press fashion, advertising, software, TV and radio, arts and crafts and fine arts.

The reason for this economic exploration of theatres is the fact that the services they provide fall into collectively provided public goods (a common feature of most cultural institutions) and that the market is not able to effectively secure these goods on the profit principle, as indicated e.g. by Loach (2017). Without the intervention from the state or territorial self-governments, the market production of some cultural goods (museums, galleries, theatres, libraries, philharmonic) would be very limited due to its economic inefficiency, as stated by e.g. Varadzin and Bečica (2016) or Vrabková et.al. (2017).

Therefore, if the historical identity and spatial availability of cultural services for current and future generations is to be preserved, it is necessary to financially support these services, as noted e.g. by Musgrave (1959), Bénard (1990), Stiglitz (2015), Řežuchová (2010), Peková (2012) or Tománek (2015). The provision rate of public 
budget funding is, however, dependent on the chosen political representation (Potůček, 2005) and several other restrictions. The basic restriction is a lack of financial resources, seeking to address these in different ways, in the public budgets, as stated by e.g. Schneider (1987) or Sedmihradská and Bakoš (2016). In view of the general lack of public sector funding, it is, therefore, necessary to implement principles of economy, efficiency, and effectiveness.

\section{Methodology and the organizations selected for the evaluation}

As already mentioned above, the purpose of the paper is to evaluate the professional theatres operating under the Association of Professional Theatres in the Czech Republic. The aim of this group is to promote the interests of their members and to provide assistance in the exchange of experience in order to streamline their management. The indicators of financial analysis have been selected for the evaluation of publicly established professional theatres based on this, in particular the profitability indicators and the modified index of autarky.

Financial analysis of non-profit organizations in the public sector has its specifics. Unlike companies based on profit that operate on the market, the main purpose of publicly established non-profit organizations (regardless of the organization's legal form) is to secure public goods for citizens and to fulfil public interest. The discovery made by del Barrio and Herrero, (2014) or Schild and Wrede (2015) suggests that the main cause of inefficiency in the functioning of cultural organizations is the lack of resource management. If progress in organizational management is noted, it is mainly due to an improvement of internal management efficiency; for example, if the organization regularly monitors economic indicators, such as profitability indicators. However, this finding is in a direct contradiction with the findings of Beutling (1986), who states that the role of culture is then receding in favour of the economy. In this paper, it is considered that due to the long-term lack of public funds in the Czech Republic, it is necessary to seek a compromise between culture and its economic aspects in order to avoid unilateral preference of the cultural aspects without measuring the economic result.

This logic is also supported by the fact that, according to the valid legislation of the Czech Republic, non-profit organizations can report profit and that way follow financial indicators. From the public funder's point of view (state, region, municipality), it is important to adhere to the $3 \mathrm{E}$ principles (economy, efficiency, effectiveness) using the means provided to ensure cultural activities. An interesting difference between the establishment of contributory organizations of self-governing-units and other types of organizations is that municipality and region can set up or establish an organization which then has a budgetary relation to the territorial self-governing unit. Morávek and Prokůpková (2015) state that the funds are not provided to the organization based on a contract, but according to the decision of the funder about the amount of the contribution, which also determines the performance and other criteria for granting of the contribution. According to the Ministry of Culture of the Czech Republic (2015), it is necessary to perceive publicly established cultural organizations as a whole-society priority as their very existence is an important element of the viability of society as a whole. 
Profitability and self-sufficiency are appropriate indicators to assess the stability of the financial position of an organization. In the case of cultural institutions, the outcomes can be directed towards an elimination of cultural experiments in favour of 'blockbuster titles'. An example of this would be the long-running and regularly sold out performance "Edith and Marlen" at the Moravian-Silesian National Theater in Ostrava or the play "The Servant of Two Masters" at the National Theater in Prague with Miroslav Donutil in the lead role.

In terms of legal status, the Association of Professional Theatres in the Czech Republic consists of three types of organizations: contributory organizations (public non-profit organizations), non-governmental organizations (public benefit companies), and trading companies (limited liability companies). Based on this, the paper studies the following hypothesis: private theatres, namely limited liability companies, are better managed, and hence represent a more stable form of theatres. A measure of the better management are the results of profitability and income self-sufficiency in theatres between 2011-2015. All of the examined theatres (although they are different in the legal form) are established by a public entity (municipality, region, state). Consequently, the paper establishes whether it is economically meaningful to transform non-profit contributory organizations into another legal form, preserving the purpose of the establishment and the funder remain.

According to the statistics of the National Information and Advisory Center for Culture (NIPOS) in 2015, 155 theatres in total, which makes 180 permanent theatre scenes altogether, have put out theatre performances in the Czech Republic. Out of these, the theatres established by private natural and legal persons still prevail in the Czech Republic (about 2/3 of the total number). However, only the publicly established professional theatres (established by the state, regions, or municipalities) are included in the evaluated organizations, managing 56 permanent theatre scenes (1/3 of the total), with their seat capacity accounting for $45 \%$ (18 676 seats) of the total seat capacity of the operated permanent theatre scenes in the Czech Republic.

Each of the indicators of the financial analysis, according to Grunwald (2009), Dluhošová (2010) or Sedláček (2011), is particularly used to assess the financial health of the private entities operating on the market; which, however, does not preclude their use in organisations managed by the public sector, as stated e.g. by Van der Pol (2008), Kislingerová (2010) or Kraft (2013). The evaluation and comparison of the socioeconomic contribution of the cultural sector with other industrial areas within the national economy is the current trend in modern societies (Throsby, 2004). UNESCO (2009) or Chiarvalloti (2014) then state that the assessment of economic importance of an organization in the culture can be carried out in different ways. As for theatre production, this can be observed for the foreign environment, for example, in the papers of Turbide and Laurin (2009), Meineck (2010), Badia and Borin (2012), Mihaiu (2014), Borg (2017) or Julien (2017).

The detected values of indicators for the financial analysis have been calculated from the data available from the balance sheet, the profit and loss account and cash flow statements, which were obtained from the available public Internet sources - the official server of the Czech justice system and the portal of the Ministry of Finance, IISSPMonitor. As observed in the literature, the financial analysis can be performed in many 
different ways. For the purpose of this paper, the calculation of the profitability indicator ratio and income self-sufficiency, according to the relationships stated below, has been chosen.

The rate of income self-sufficiency of the organization can be described through the following relationship:

Rate of income self - sufficiency $=\frac{\text { own budget revenue }}{\text { total revenue }}$

Indicators of profitability (return) are among the most closely watched ratio indicators of the financial analysis since they convey information about the effect triggered by an injected capital. They express how many crowns of profit fall on one crown of the injected capital. There are many indicators of profitability; the crucial and in practice most used, according to Brigham and Ehrhardt (2011), being:

Return on assests $(R O A)=\frac{\text { net income for accounting period }(E A T)}{\text { assets }}$.

ROA is considered a key indicator of profitability, as it measures profit with total assets, regardless of what sources these assets are financed by.

Retrun on capital emloyed $($ ROCE $)=\frac{\text { earrnings before interest and taxes }(E B I T)}{\text { equity+long-term obligations }}$.

The long-term debts enter the indicators of ROCE, which can include bonds issued, long-term bank loans and equity capital. ROCE expresses just the effectiveness of the management of the organization, regardless of what resources the capital comes from.

Return on equity $(R O E)=\frac{\text { net income for accounting period }(E A T)}{\text { equity }}$.

As for profitability, the indicator that companies monitor the most is the one of return on equity. Founders, shareholders, as well as investors focus on ROE. This indicator articulates the profitability of the company's own resources and also their appreciation (in net profit).

Return on sales $(R O S)=\frac{\text { net income for accounting period }(E A T)}{\text { sales }}$.

Return on sales is useful especially for comparisons of homogeneous entities and for a comparison over time. This commonly observed indicator in particular reflects the reference to the management level of the organization from the perspective of management. The higher the indicator, the better and more capable management the organization has.

\section{Results}

Figure 1 demonstrates the calculated average rate of income self-sufficiency for the professional theatres in the period 2011-2015. The Municipal Theatre in Kladno, a limited liability company, has been excluded from the sample as it has not made available any data necessary for the calculation, despite being repeatedly asked to. 
Figure 1. The average rate of income self-sufficiency of professional theatres for $2011-2015$ in \%

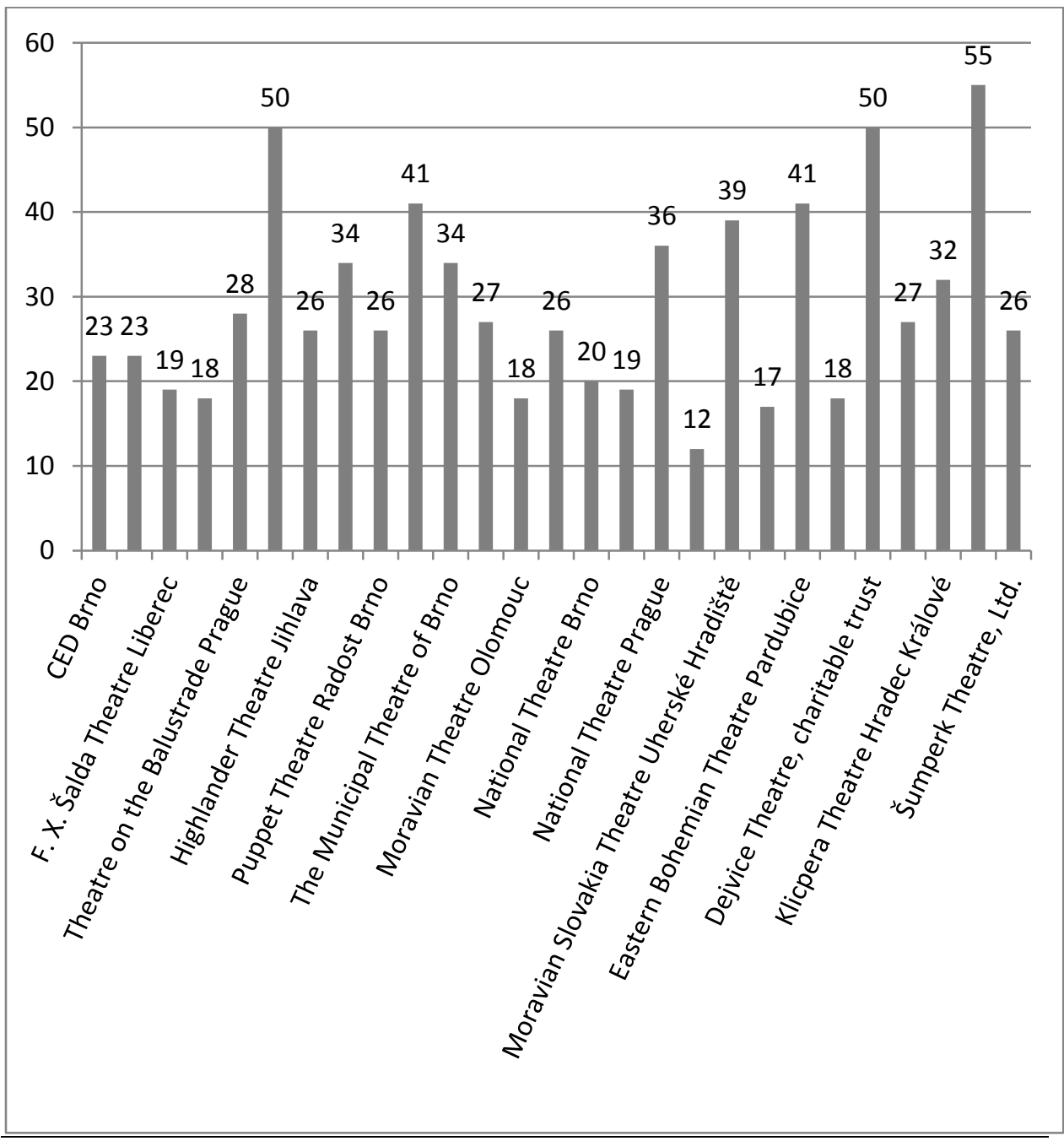

Source: the author's own processing based on the data available from the accounting statements for 2011-2015

The North Bohemian Theatre of Opera and Ballet exhibits the highest rate of selfsufficiency with its $55 \%$, which is quite paradoxical since, as shall be observed soon below, this theatre ranks among the worst in terms of profitability.

Among the best-ranked of the theatres regarding their income self-sufficiency are the Antonín Dvořák Theatre in Př́bram and the Dejvice Theatre (50\%). A relatively high self-sufficiency of $41 \%$ was then reported by the East Bohemian Theatre Pardubice and The Municipal Theatres of Prague. 
The Silesian Theatre Opava (12\%) reported the weakest rate of income self-sufficiency, followed by the Těšín Theatre in Český Těšín (17\%), the J. K. Tyl Theatre in Pilsen (18\%), the Moravian Theatre Olomouc (18\%) and the West Bohemian Theatre Cheb $(18 \%)$. A common feature of these theatres is the multi-genre of performance repertoir, always producing minimally two genres - drama, operetta, musical, opera, ballet, puppetry, etc.. Many of theatres showing a low self-sufficiency, fall short of their own resources for running the theatre, but the resources accruing to them from the funders are so high that the theatre can easily and professionally operate, often even better than theatres with a high autonomy but low on support from external entities (funders, state, city, the Ministry of Culture, donators, etc.). A good example would the J. K. Tyl Theatre in Pilsen, which achieves the best results in profitability; however, its rate of income self-sufficiency is one of the weakest in the sample. The exact opposite can be observed for the Antonín Dvořák Theater in Př́bram: a high level of self-sufficiency has been discovered, yet accompanied by one of the worst profitability results.

Table 1 below shows the individual results of profitability, a synonym of return, which expresses the organization's ability to achieve profit based on the money invested.

In addition to the average values for the period 2011-2015, each of the profitability indicators has a corresponding trend assigned: $\uparrow=$ a growing trend, $\downarrow=$ downward trend, $\rightarrow=$ fluctuating trend. For each of the indicators, five best rated theatres (light grey background) and five worst-rated theatres (dark grey background) are highlighted.

The individual profitability indicators do not have precisely specified recommended result values; however, the higher the values determined for specific indicators are, the better evaluation for the organization. The trend, considering which the organization should wend its way, is growing in all of the profitability indicators.

The J. K. Tyl Theatre in Pilsen, the Highlander Theatre Jihlava and the Naive Theatre in Liberec show a growing trend of all of the profitability indicators over the examined period. In these theatres, there is a prerequisite for an effective future development regarding profitability. The table nonetheless also captures many negative values of profitability indicators, which could be contributed especially to the negative economic result that the given organisations proved.

As far as profitability indicators alone are concerned, the key indicator is return on assets (ROA), which expresses the profit ratio with entire assets of the company. A negative trend can be observed for five of the professional theatres: North Bohemian Theatre of Opera and Ballet, Antonín Dvořák Theatre Příbram, South Bohemian Theatre České Budějovice, National Theatre Brno, Šumperk Theatre. The rest of the sample shows a positive value. The best return on assets has been recorded for the J. K. Tyl Theatre in Pilsen, mainly due to the return on assets of almost $8 \%$ in 2014. This means that the net profit after tax was CZK 0.08 per CZK 1 of assets. In 2015, the J. K. Tyl Theatre recorded a decrease in this indicator, mainly due to a decreasing after-tax profit of $67.62 \%$, while for the previous years the organization exhibits a growing trend of the indicator in accordance with the recommendation. Apart from the J. K. Tyl Theatre in Pilsen, the Drak Theatre in Hradec Králové, the Moravian Slovakia Theatre in Uherské Hradiště, the Moravian Theatre in Olomouc and the Municipal Theater of Prague have all also come out with good values. Each of these theatres has a return on 
assets above $1 \%$. Only the J. K. Tyl Theatre in Pilsen and the Drak Theatre in Hradec Králové show more than $2 \%$ of ROA.

Table 1. The average profitability indicators of professional theatres for 2011 2015 in \%

\begin{tabular}{|c|c|c|c|c|}
\hline PROFITABILITY & ROA & ROCE & ROE & ROS \\
\hline CED Brno & $0,37 \downarrow$ & $0,54 \downarrow$ & $0,42 \downarrow$ & $1,62 \downarrow$ \\
\hline ALFA Theatre Pilsen & $1,12 \rightarrow$ & $1,17 \rightarrow$ & $1,17 \rightarrow$ & $11,13 \rightarrow$ \\
\hline F. X. Šalda Theatre Liberec & $0,03 \downarrow$ & $0,04 \downarrow$ & $0,04 \downarrow$ & $0,26 \downarrow$ \\
\hline J. K. Tyl Theatre in Pilsen & $3,47 \uparrow$ & $4,28 \uparrow$ & $4,28 \uparrow$ & $16,42 \uparrow$ \\
\hline Theatre on the Balustrade Prague & $0,37 \downarrow$ & $0,42 \downarrow$ & $0,42 \downarrow$ & $1,54 \downarrow$ \\
\hline Theatre A. Dvořák in Př́ibram & $-1,16 \rightarrow$ & $-1,59 \downarrow$ & $-1,63 \rightarrow$ & $-0,46 \rightarrow$ \\
\hline Highlander Theatre Jihlava & $0,19 \uparrow$ & $0,20 \uparrow$ & $0,17 \uparrow$ & $2,15 \uparrow$ \\
\hline South Bohemian Theatre České Budějovice & $-0,66 \rightarrow$ & $-0,71 \rightarrow$ & $-0,74 \rightarrow$ & $-2,66 \rightarrow$ \\
\hline Puppet Theatre Radost Brno & $0,11 \rightarrow$ & $0,11 \rightarrow$ & $0,10 \rightarrow$ & $1,60 \rightarrow$ \\
\hline The Municipal Theatres of Prague & $1,13 \uparrow$ & $1,46 \uparrow$ & $1,33 \rightarrow$ & $1,13 \uparrow$ \\
\hline The Municipal Theatre of Brno & $0,03 \rightarrow$ & $0,03 \downarrow$ & $0,03 \downarrow$ & $0,18 \rightarrow$ \\
\hline The Municipal Theatre of Zlín & $0,90 \rightarrow$ & $1,17 \rightarrow$ & $1,05 \rightarrow$ & $4,45 \rightarrow$ \\
\hline Moravian Theatre Olomouc & $1,36 \rightarrow$ & $1,49 \rightarrow$ & $1,43 \rightarrow$ & $18,33 \rightarrow$ \\
\hline Naive Theatre Liberec & $0,47 \uparrow$ & $0,52 \uparrow$ & $0,49 \uparrow$ & $2,90 \uparrow$ \\
\hline National Theatre Brno & $-0,51 \downarrow$ & $-0,53 \downarrow$ & $-0,54 \rightarrow$ & $-4,30 \rightarrow$ \\
\hline National Moravian-Silesian Theatre Ostrava & $0,38 \rightarrow$ & $0,42 \uparrow$ & $0,39 \uparrow$ & $5,43 \uparrow$ \\
\hline National Theatre Prague & $0,40 \rightarrow$ & $0,63 \rightarrow$ & $0,45 \rightarrow$ & $3,11 \rightarrow$ \\
\hline Silesian Theatre Opava & $0,36 \rightarrow$ & $0,37 \rightarrow$ & $0,37 \rightarrow$ & $8,56 \rightarrow$ \\
\hline Moravian Slovakia Theatre Uherské Hradiště & $1,57 \rightarrow$ & $5,19 \downarrow$ & $5,18 \downarrow$ & $1,62 \rightarrow$ \\
\hline Těšín Theatre in Český Těšín & $0,00 \rightarrow$ & $0,01 \downarrow$ & $0,00 \rightarrow$ & $0,00 \rightarrow$ \\
\hline Eastern Bohemian Theatre Pardubice & $0,76 \rightarrow$ & $2,49 \rightarrow$ & $2,42 \rightarrow$ & $0,70 \rightarrow$ \\
\hline West Bohemian Theatre Cheb & $0,08 \rightarrow$ & $0,09 \rightarrow$ & $0,09 \rightarrow$ & $0,38 \rightarrow$ \\
\hline Dejvice Theatre, charitable trust & $0,08 \downarrow$ & $0,43 \downarrow$ & $0,43 \downarrow$ & $0,22 \downarrow$ \\
\hline Drak Theatre in Hradec Králové & $2,78 \rightarrow$ & $3.58 \rightarrow$ & $3,10 \rightarrow$ & $12,78 \rightarrow$ \\
\hline Klicpera Theatre Hradec Králové & $0,72 \rightarrow$ & $1,24 \rightarrow$ & $1,24 \uparrow$ & $0,84 \uparrow$ \\
\hline North Bohemian Theatre of Opera and Ballet, & $-20,74 \downarrow$ & $-21,76 \downarrow$ & $-21,76 \downarrow$ & $\mathrm{x}$ \\
\hline Šumperk Theatre, Ltd. & $-0,23 \rightarrow$ & $-0,24 \rightarrow$ & $-0,25 \rightarrow$ & $-0,87 \rightarrow$ \\
\hline$\downarrow$ trend - total number & 6 & 10 & 7 & 4 \\
\hline$\rightarrow$ trend - total number & 17 & 12 & 15 & 16 \\
\hline$\uparrow$ trend - total number & 4 & 5 & 5 & 6 \\
\hline
\end{tabular}

Source: the author's own processing based on the data available from the accounting statements for 2011-2015 
Another profitability indicator is return on capital employed (ROCE). A negative development has been found for the same 5 theatres of the Association as in the case of the ROA indicator. Among the most successful organizations regarding long-term profitability is the Moravian Slovakia Theatre in Uherské Hradiště. The average value of ROCE for the period 2011-2015 is 5.19\%. 2013 was a year of crisis owing to the negative profitability figures reported. In other years, however, ROCE proves to be positive; for example, in 2014 it was of $9.14 \%$ value. 9 theatres show the profitability of long-term resources above $1 \%$. Above $2 \%$ can be found in the case of ROCE in the Moravian Slovakia Theatre, the J. K. Tyl Theatre in Pilsen, the Drak Theatre in Hradec Králové and the East Bohemian Theatre Pardubice.

The Moravian Slovakia Theatre in Uherské Hradiště has again ranked the best in terms of return on equity (ROE). The average of ROE turns out to be 5.18\% for 2011-2015. 9 out of 27 theatres in total exhibit ROE above 1\%. The Moravian Slovakia Theatre in Uherské Hradiště, the J. K. Tyl Theatre in Pilsen, the Drak Theatre in Hradec Králové and the East Bohemian Theatre in Pardubice all have ROE above 2\%.

The value of the profitability indicator of equity should be higher than the value of the profitability of assets. Considering the average values again, this condition has not been met in 8 theatres. The reason behind this is a low value of operating profit. If the organization was entirely self-financed, the value of ROA would be equal to the value of ROE.

Low values of indicators of return on sales (ROS) demonstrate a bad management of the company. This indicator expresses the organization's ability to achieve a profit with the given level of sales in the organization. Return on sales in theatres is related to the charges for admission. The North Bohemian Theatre of Opera and Ballet has not provided any useful data to calculate this indicator - hence the ' $x$ ' in the table. Negative values of ROS have been calculated for 4 theatres: National Theatre Brno, South Bohemian Theatre České Budějovice, Šumperk Theatre and Antonín Dvořák Theatre. The Moravian Theatre Olomouc has ranked best in terms of ROS with its $18.33 \%$ value for the examined period. The highest profitability of sales has been calculated for the Moravian Theatre Olomouc in 2012 at 25\%. 15 theatres then show ROS above $1 \%$. ROS above $2 \%$ can be found in 10 theatres and above $10 \%$ in 4 theatres: Moravian Theatre Olomouc, J. K. Tyl Theatre in Pilsen, Drak Theatre Hradec Králové, Theatre ALFA Pilsen.

\section{Discussion}

A total of 5 organizations have exhibited a degree of self-sufficiency higher than $40 \%$. The reason for this positive development can be assigned to several factors. One of the most pronounced ones are a lower frequency and smaller number of performances, the selection of the repertoire (usually well-known dramatic titles starring well-known actors) and a smaller auditorium that automatically increases the number of sold-out performances and revenue of the organization. From an economic point of view, the fixed (especially operating) costs of the organization per unit (one seat sold $=$ one visitor) decreases automatically. As for theatre production, it is important to note that lower costs can be observed for drama performances with fewer actors (usually 2-15) and lower demands on costumes and backdrops. Whereas it is financially difficult to 
realize more complex genres such as operettas, musicals, operas or ballets, that require, besides actual actors on stage, number of other artistic professions (especially musicians, singers and dancers). This can be seen demonstrated in the results of selfsufficiency with multi-genre theatres with a larger number of stages and greater capacity of auditoriums (such as the Moravian Theatre in Olomouc, the J. K. Tyl Theatre in Pilsen, the National Theatre in Brno, the National Moravian-Silesian Theatre in Ostrava). An exception to this group of multi-genre theatres, due to the level of selfsufficiency found, is the National Theatre in Prague, owing to higher ticket prices (about two to three times higher) than in other multi-genre theatres. In general, a higher price of tickets at theatres in Prague and the surrounding area responds to a higher demand for public services provided by them, which is positively reflected in the revenues, specifically the self-sufficiency of Prague and Central Bohemian theatres. This fact is confirmed by the survey of the National Information and Advisory Center for Culture, where the statistics show that Prague and its surroundings are about one level higher in terms of the number of private (not always market-established) established cultural institutions (including theatres).

The higher attendance of the theatre performances in Prague and the surrounding area is caused by, among other things, the number of tourists from abroad visiting the National Theatre (historical building, the Estates Theatre, the State Opera). In the case of onegenre theatres (most often dramas or puppetry), it is an attraction for visitors to see public figures of the Czech cultural scene in action - for example the well-known personalities of the Prague Municipal Theatres (like Stanislav Zindulka, Petr Štěpánek, Tat’jána Medvecká, Oldřich Vízner, Simona Stašová, Michal Dlouhý, Martin Písařík, Zuzana Kajnarová) or the Dejvice Theatre (such as Martha Issová, Miroslav Krobot, Martin Mousek, Ivan Trojan, Matěj Hádek).

From the aggregate results of each type of profitability, it is evident that the number of organizations in terms of the reported trend does not change fundamentally over time. Only $20 \%$ of the surveyed organization sample reach the recommended rising values (as is stated by Brigham and Ehrhardt, 2011 or Dluhošová, 2010), and again, it mostly concerns theatres with single-genre and smaller sized theatres. The exception is, in this case, the multi-genre J. K. Tyl Theatre in Pilsen, which could have been influenced by the fact that the City of Pilsen was in 2015 proclaimed one of the main European cities of culture. In connection to the preparations for this event, in 2012 the statutory City of Pilsen commenced construction of an entirely new theatre building (now "The New Stage" of the J. K. Tyl Theatre in Pilsen), which was inaugurated on September 2, 2014 at the cost of 870 million crowns. The opening of a new theatre building (one of the most modern theatre scenes in Europe) has contributed to a higher attendance and higher sales, which has positively influenced individual profitability indicators.

Considering the above-described facts, it can be observed that a higher degree of income self-sufficiency and better indicators of profitability can be found with singlegenre theatres, and, in terms of the size of auditorium, in rather small theatres focusing on drama (Prague Municipal Theatres, Dejvice Theatre, Moravian Slovakia Theatre Uherské Hradiště or the children's production in Hradec Králové) that are very selective of its repertoire, which is welcomed especially by a less demanding visitor of the theatre. 


\section{Conclusion}

Culture in an inseparable part of the life of every individual, both consciously (going to a theatre) and unconsciously (listening to music). This paper has examined reviews of homogeneous organizations that provide public goods with collective consumption in the cultural field, specifically entities in the field of stage arts, i.e. the part of the culture that includes theatrical production. The aim of the paper has been the assessment of profitability indicators and the rate of income self-sufficiency for theatres operating under the Association of Professional Theatres in the Czech Republic between 20112015 which includes 28 entities in total. Better results have generally been obtained for single-genre theatres, and, in terms of the auditorium size, for smaller theatres focusing on drama or children's production.

The best results of profitability indicators have been calculated for the J. K. Tyl Theatre in Pilsen, the Drak Theatre Hradec Králové and the Moravian Slovak Theatre Uherské Hradiště, which all are, except for the J. K. Tyl Theatre in Pilsen, one-genre theatres. The worst results have been obtained for the North Bohemian Theatre of Opera and Ballet Ústí nad Labem, the Antonín Dvořák Theatre in Př́bram and the South Bohemian Theatre in České Budějovice, which are all multi-genre theatres.

As for the rate of income self-sufficiency, professional theatres in the Czech Republic are dependent on resources from public budgets (the state budget, budgets of territorial self-governing units or state funds). The greatest dependence on these resources has been identified in the Silesian Theatre in Opava, which between 2011-2015 reports the average rate of income self-sufficiency of only $12 \%$, meaning the average dependency on the funder's resources was $88 \%$. Interestingly, the city of Opava providing the necessary resources for the proper functioning of the Silesian Theatre does not result in cumulating losses. In contrast, the North Bohemian Theatre of Opera and Ballet Ústí nad Labem has the highest rate of income self-sufficiency at 55\%, i.e. dependence on foreign resources is only 45\%; yet the funder, who are the town of Ústí nad Labem and the Ústí Region together, does not provide resources on such a level so that the theatre would start cumulating profits. Throughout the examined period, even in 2010 and 2011 when the theatre was a contributory organisation of the statutory city of Ústí nad Labem, the theatre has experienced a loss, which through transformation of legal form of the organization into a trading company or a limited liability company has not diminished but rather increased several times.

In terms of profitability indicators, the values discovered in the theatres do not correspond with the standard values of indicators for private enterprises, where profitability and income indicators are commonly observed, as noticeable differences between examined organisations are visible. The output of a theatre is the production output of the cultural experience for the population, which is significantly different from the output of a typical company producing a particular product and operating in a competitive environment on the market. However, the above mentioned may be applied for an assessment of homogeneous production, and it can be stated that the methods used in the paper are not commonly applied in public sector organisations but can still be used; and when properly interpreted, they also have the appropriate informative value. 
The hypothesis determined in the introduction can be refuted on the basis of the above results, as private companies dealing with theatrical production, or rather limited companies (North Bohemian Theatre of Opera and Ballet, Municipal Theatres Kladno, Šmperk Theatre) are not better managed and do not represent more stable companies than most of the contributory organizations in the sample. Based on the results of the profitability indicators and the rate of income self-sufficiency, these entities rank among the economically weaker companies and show, for the most part, some of the worst results of the sample survey, and additionally do not publish the information necessary for comparison even though their funder is a $100 \%$ public entity (Municipal Theatre Kladno). It has also been discovered that what also is of economic importance is not transforming of non-profit contributory organizations of the public funder into another legal form when the purpose of the establishment and the founder remain preserved.

Focusing on culture, theatres and stage art abroad, we obtain similar results from Meineck (2010), who deals with this issue at the level of the United States, or Julien (2017), who deals with the operation of theatres in Canada. As for European authors, e.g. Corboş and Popescu (2013) study the role of theatres in improving the competitiveness of Romanian Bucharest. Their work follows an interesting finding that the theatre can become a unique cultural centre which contributes to the strategic development of the territory. Regarding Czech authors, the viability of organizations in the cultural sector is dealt with e.g.by Hamerníková (1995), Škarabelová (2007), Dostál and Kislingerová (2012) or Vrabková. (2017).

What seems to be a fitting conclusion to this paper is Milan Kundera's notion that a nation bereft of culture is sentenced to death. Everyone takes part in culture, even if they are unaware of it. Therefore, the approach of individual residents and their elected representatives, and accordingly the financial support from public and private resources in the culture should improve in the future.

Funding: The paper was written with the financial support of the student grant project SGS No. SP2017/129 "Economic Factors Affecting the Ensuring of Public Services with Collective Consumption" of the Faculty of Economics, Technical University of Ostrava and the project "Methodological Application Tools for Effective Financial Management of Territorial Structured Statutory City" in the program Éta of Technological Agency of the Czech Republic, No. TL01000145.

Disclosure statement: No potential conflict of interest was reported by the author.

\section{References}

BADIA, F., BORIN, E. (2012). Opportunities and Critical Points for the Introduction of Performance Measurement Systems in Theatres - A Comparison between Theoretical Assumptions and Empirical Realities. Journal of Cultural Management and Policy. Vol. 2, No. 2, pp. 45-59.

BÉNARD, J. (1990). Veřejná ekonomika I. Prague: EÚ ČSAV.

BEUTLING, L. (1986). Company Accounting and Accounting of Public Theatres as Instruments for Securing of thein Profitability or more Economic-efficiency in 
Theatres - The End of the Arts. Betriebswirtschaftliche forschung ung praxis. Vol. 38. Issue 1. Pp 80-91.

BORG, R. P. (2017). A Methodology for the Quality Assessment of the Theatre. In V. A. Cremona (ed.), Capitalising on culture? Malta and the European capital of culture. pp. 77-96. Msida: Malta University Publishing.

BRIGHAM, E. R., EHRHARDT, M. C. (2011). Financial Management. Theory and Practice. 13 th ed. South - Western Cengage Learning, 1152 p. ISBN 978-1-43907809-9.

CHIARAVALLOTI, F. (2014). Performance Evaluation in the Arts and Cultural Sector: A Story of Accounting at Its Margins. The Journal of Arts Management, Law, and Society, 44(2), 61-89. ISSN 1063-2921. DOI: 10.1080/10632921.2014.905400

CORBOS, R. A., POPESCU, R. I. (2013). Study regarding Theatres' role in increasing urban competitiveness. Administratie si Management Public. no. 20, pp. 78 - 96. ISSN 15839583.

Del BARRIO, MJ., HERRERO, LC. (2014). Evaluating the Efficiency of Museums Using Multiple Outputs: Evidence from Regional System of Museums in Spain. International Journal of Cultural Policy. Vol. 20, Issue 2. Pp. 221-238. DOI: $\underline{10.1080 / 10286632.2013 .764290}$

DLUHOŠOVÁ, D. et al. (2010). Finanční ř́zení a rozhodování podniku. 3rd ed. Prague: Ekopress, p. 225. ISBN 978-80-86929-68-2.

DOSTÁL, P., KISLINGEROVÁ, E. (2012). Ekonomika kultury: efektivní metody a nástroje sektoru kultury. 1st ed. Prague: Oeconomica. ISBN 978-80-245-1886-2.

GRÜNWALD, R., HOLEČKOVÁ, J. (2009). Finanční analýza a plánování podniku. $1^{\text {st }}$ ed. Prague: Ekopress, p. 318. ISBN 978-80-86929-26-2.

HAMERNÍKOVÁ, B. (1995). Kultura a masmédia $v$ tržních podmínkách. $1^{\text {st }}$ ed. Prague: VŠE. 207 s. ISBN 80-7079-857-2.

JULIEN, M. (2017). Community, viability: Theatre past and present. Canadian Theatre Review. No. 169, p. 78 - 83. ISSN 03150836. DOI: $10.3138 /$ ctr.169.013

KISLINGEROVÁ, E. et.al. (2010). Manažerské finance. $3^{\text {rd }}$ ed. Prague: C. H. Beck. 864 s. ISBN 978-80-7400-194-9.

KRAFTOVÁ, I. (2002). Finanční analýza municipálni firmy. Prague: C. H. Beck, 2002, 206 p. ISBN 80-7179-778-2.

KRAFTOVÁ, I., PRÁŠILOVÁ, P. (2013). Prosperujici podnik v regionálním kontextu. Prague: Wolters Kluwer ČR. ISBN 978-80-7357-989-0.

LOACH, K., ROWLEY, J., GRIFFITHS. J. (2017). Cultural sustainability as a strategy for the survival of museums and libraries. International Journal of Cultural Policy. Vol. 23, Issue 2, Pages 186-198. ISSN 1028-6632.

MEINECK, P. (2010). Page and stage: Theater, tradition, and culture in America. Classical World. no. 103, issue 2, p. 221 - 226. ISSN 00098418. DOI: $\underline{10.1353 / \mathrm{clw} .0 .0173}$ 
MIHAIU, D. (2014). Measuring Performance in The Public Sector: Between Necessity and Difficulty. Studies in Business and Economics, Vol. 9, No. 2, pp. 40-50.

MINISTERSTVO KULTURY ČR. (2015). Státní kulturní politika na léta 2015 - 2020. [online]. [cit. 2017-11-27]. Available at: https://www.mkcr.cz/statni-kulturni-politika69.html.

MORÁVEK, Z., PROKŮPKOVÁ, D. (2015). Př́spěvkové organizace 2015. 2. vyd. Prague: Wolters Kluwer ČR. 290 p. ISBN 978-80-7478-833-8.

MUSGRAVE, R. A. (1959). The Theory of Public Finance. New York: McGraw-Hill.

NIPOS: Statistical data in publications - Culture statistics. [online]. [cit. 2018-04-15]. Available from: https://statistikakultury.cz/wp-content/uploads/2017/11/Statistika-2016divadla.pdf

OCHRANA, F. et al. (2007). Efektivnost zabezpečování vybraných veřejných služeb na úrovni obcí. Prague: Oeconomica.

PEKOVÁ, J., PILNÝ, J., JETMAR, M. (2012). Veřejný sektor - řizení a financování. Prague: Wolters Kluwer ČR. 485 p. ISBN 978-80-7357-936-4.

POTU゚ČEK, M. et al. (2005). Veřejná politika. Prague: Sociologické nakladatelství (SLON). 399 p. ISBN 80-86429-50-4.

RICHTER, V. (2015). Srovnávání knihoven se vyplatí. Čtenář. Vol. 67, No.5, pp. 163166.

ŘEŽUCHOVÁ, M. (2010). Partnerství veřejného a soukromého sektoru: Analýza možností efektivního zabezpečování veřejných služeb. Disertační práce. Brno: Masaryková univerzita Brno. Available: http://is.muni.cz/th/77468/esf_d/

SCHILD, CJ., WREDE, M. (2015). Cultural identity, mobility and decentralization. Journal of Comparative Economics. Vol. 43. Issue 2. pp 323-333.

SCHNEIDER, M. (1987). Local Budgets and the Maximization of Local Property Wealth in the System of Suburban Government. The Journal of Politics, 49(4) DOI: $10.2307 / 2130787$

SEDLÁČEK, J. (2011). Finanční analýza podniku. $2^{\text {nd }}$ ed. Brno: Computer Press. p. 160. ISBN 978-80-251-3386-6.

SEDMIHRADSKÁ, L., BAKOŠ, E. (2016). Municipal Tax Autonomy and Tax Mimicking in Czech Municipalities. Lex Localis - Journal of Local Self-Government. 14(1), 75-92.

STIGLITZ, J. E., ROSENGARD, J. K. (2015). Economics of the Public Sector. $4^{\text {th }}$ ed. New York: W. W. Norton Company.

STEJSKAL, J. et al. (2013). Měřeni hodnoty služeb (na přikladu veřejných knihoven). Prague: Wolters Kluwer ČR.

ŠKARABELOVÁ, S., NESHYBOVÁ, J., REKTOŘÍK, J. (2007). Ekonomika kultury a masmédii. $1^{\text {st }}$ ed.: ESF MU. 210 p. ISBN 978-80-210-4267-4. 
THROSBY, D. (2004). Assessing the impacts of a cultural industry. Journal of Arts Management, Law Society, 34(3), 188-204. DOI: 10.3200/JAML.34.3.188-204

TOMÁNEK, P. (2015). Aspects of spatial distribution of tax revenues in terms of usage in regional budgets. In: Theoretical and Practical Aspects of Public Finance 2015: proceedings of the 20th international conference. Praha: Oeconomica, 2015. pp. 267272. ISBN 978-80-245-2094-0.

TURBIDE, J., LAURIN, C. (2009). Performance Measurement in the Arts Sector: The Case of the Performing Arts. International Journal of Arts Management. 2009, Vol. 11, No. 2, pp. 56-70.

UNESCO. (2009). Measuring the economic contribution of cultural industries. A review and assessment of current methodological approaches. [online]. 2009 [cit. 2017-11-20]. Available: http://uis.unesco.org/sites/default/files/documents/measuring-the-economiccontribution-of-cultural-industries-a-review-and-assessment-of-current-methodologicalapproaches-en_1.pdf.

VAN DER POL, H. (2008). Key role of cultural and creative industries in the economy. In Statistics, Knowledge and Policy. Measuring and Fostering the Progress of Societies. Paris and Washington, D.C. OECD. 343-353.

VARADZIN, F., BEČICA, J. (2016). Sídla a produkční potenciál. (fungování a ekonomický potenciál obci v ČR s príklady z území Moravskoslezského kraje). Prague: Professional Publishing. 180 p. ISBN 978-80-906594-0-7.

VAVREK, R., ADMISIN, P., KOTULIC, R. (2014). Impact of Indicator Weight of Topsis Technique in Assessing of Municipalities. In: 12th International Conference on Hradec Economic Days (HED 2014): Economic Development and Management of Regions Location. Hradec Kralove: Univ Hradec Kralove. pp. 373-382. ISBN 978-807435-368-0.

VRABKOVÁ, I., et al. (2017). Př́spěvkové organizace: postavení, úkoly a technická efektivnost, SAEI, vol. 47. Ostrava: VSB-TU Ostrava. ISBN 978-80-248-4028-4.

WANG, S., et.al. (2016). Using DEA Models to Measure the Performance of Public Culture Services in China. In Computational Science and Computational Intelligence (CSCI), Las Vegas, pp. 1-10.

ŽÁKOVÁ, E. et al. (2017). Mapováni kulturních a kreativnich průmyslů v $\check{C} R$ Vymezení, kvantitativní mapování a strategické dokumenty. [online]. [cit. 2017-11-18]. Available: http://www.idu.cz/cs/mapovani-kulturnich-a-kreativnich-prumyslu-v-cr. 